7. Падалка Г.М. Педагогіка мистецтва (Теорія і методика викладання мистецьких дисциплін). Київ : Освіта України, 2010. 274 с.

8. Рождественская Н.В., Толшин А.В. Креативность : пути развития и тренинги. Санкт-Петербург : Речь, 2006. 320 c.

\title{
References
}

1. Antonova, O. E. (2012). The Essence of the Notion of Creativity: Problems and Quest. Theoretical and Applied Aspects of the Development of Creative Education in Higher Education: Monograph. Zhytomyr : Vyd-vo ZHDU im. Ivan Franko. [in Ukrainian].

2. Vishnyakova, N. F. (1996). Psychological Foundations of Creativity Development in Professional Acmeology. Moscow : Azbuka-Atticus, 31. [in Russian].

3. Judkins, R. (2016). The Art of Creative Thinking. Moscow : Azbuka Business. [in Russian].

4. Zaitsev, V.P. (2006). Direction of Stage and Mass Spectacles : Tutorial for students of higher education institutions. Kyiv: Dakor. [in Ukrainian].

5. Creativity as a Skill to Dispose of Ideas. Retrieved from : https://telekritika.ua/uk/kino/kreativnist-yakmajsternist-rozporyadzhatisya-ideyami.

6. Creativity without Borders. 7 TED speeches about creativity. Retrieved from : https://life.pravda.com.ua/society/2016/08/6/216219/.

7. Padalka, G.M. (2010). Pedagogics of Arts (Theory and Methodology of Discipline of Arts). Kyiv : Osvita Ukrainy. [in Ukrainian].

8. Rozhdestvenskaya, N.V., Tolshyn, A.V. (2006). Creativity: Ways of Development and Trainings. St. Petersburg: Rech. [in Russian].

Стаття надійшла до редакції 11.06.2019 p.

УДК 792.82(477)

Лук'яненко Катерина Аркадіївна

Аспірант Київського національного університету культури і мистецтв

ORCID 0000-0003-1490-4601

katechoreography@gmail.com

\section{ТВОРЧІ ПОШУКИ БАЛЕТМЕЙСТЕРІВ УКРАЇНСЬКОГО БАЛЕТНОГО ТЕАТРУ В 1960-ті РОКИ}

\begin{abstract}
Мета статті - виявити особливості творчої діяльності балетмейстерів-шістдесятників у контексті еволюціонування українського балетного театру за «доби П. Шелеста» (1963-1972 рр.). Методологія дослідження. Застосовано метод історизму (для дослідження суспільно-політичних умов та культурно-мистецьких тенденції означеного періоду); культурологічний метод, що посприяв дослідженню діяльності балетмейстерівшістдесятників у контексті розвитку української культури; методи порівняльного аналізу та стильового підходу, спрямовані на визначення специфріки хореографічної структури балетних постановок та ін. Наукова новизна. Визначено тенденції розвитку українського балетного мистецтва відповідно до специфіки суспільно-політичного та культурно-мистецького життя 1963-1972 рр.; виявлено специфіку творчих пошуків балетмейстерівшістдесятників у контексті еволюціонування українського балетного театру за «доби П. Шелеста»; простежено особливості взаємодії народного та класичного танцю в постановках балетмейстерів-шістдесятників. Висновки. Постановки українських балетмейстерів-шістдесятників вирізняються нестандартністю вирішення образів, оригінальністю та індивідуальністю, репрезентують приклади новаторського режисерського рішення вже здійснених іншими балетмейстерами постановок та першопрочитання хореографічних творів. Суспільно-політичні умови та культурно-мистецькі тенденції 1963-1972 рр. відобразилися на специфіці еволюціонування українського балетного театру, проявившись передусім в активізації спроб розширити межі художньої мови засобами використання широких узагальнюючих образів, стилізації народного танцю або його елементів, переході до непрямого цитування фольклорних першоджерел та збагачення хореографічної образності в контексті відображення сучасної проблематики. Деякі вистави вітчизняних балетмейстерів-шістдесятників позиціонуються як розвідка нових шляхів у балетному мистецтві, що сприяли формуванню новаторських тенденцій хореографічного театру та розвитку нових виражальних засобів балету. Їх творчість відображає різноманітні жанри, форми, лексику та напрямки балетного театру в культурі України 1960-х рр. льні засоби.

Ключові слова: український балетний театр, балетмейстери-шістдесятники, балетна вистава, виражаи искусств

Лукьяненко Екатерина Аркадьевна, аспирантка Киевского национального университета культуры

Творческие поиски балетмейстеров украинского балетного театра в 1960-е годы

Цель статьи - выявить особенности творческой деятельности балетмейстеров-шестидесятников в контексте эволюционирования украинского балетного театра «эпохи П. Шелеста» (1963-1972 гг.). Методология исследования. Применен метод историзма (для исследования общественно-политических условий и культурных тенденции определенного периода); культурологический метод, который помог исследованию деятельности ба-
\end{abstract}

(C) Лук'яненко К. А., 2019 
летмейстеров-шестидесятников в контексте развития украинской культуры; методы сравнительного анализа и стилевого подхода, направленные на определение специфики хореографической структуры балетных постановок и др. Научная новизна. Определены тенденции развития украинского балетного искусства в соответствии со спецификой общественно-политической и культурной жизни 1963-1972 гг.; выявлена специфика творческих поисков балетмейстеров-шестидесятников в контексте эволюционирования украинского балетного театра «эпохи П. Шелеста»; прослежены особенности взаимодействия народного и классического танца в постановках балетмейстеров-шестидесятников. Выводы. Постановки украинских балетмейстеров-шестидесятников отличаются нестандартностью решения образов, оригинальностью и индивидуальностью, представляют примеры новаторского режиссерского решения уже осуществленных другими балетмейстерами постановок и первопрочтения хореографических произведений. Общественно-политические условия и культурно-художественные тенденции 19631972 гг. отразились на специфике эволюционирования украинского балетного театра, проявившись прежде всего в активизации попыток расширить границы художественного языка средствами использования широких обобщающих образов, стилизации народного танца или его элементов, переходе к косвенному цитирование фольклорных первоисточников и обогащения хореографической образности в контексте отображения современной проблематики. Некоторые представления отечественных балетмейстеров-шестидесятников позиционируются как разведка новых путей в балетном искусстве, что способствовали формированию новаторских тенденций хореографического театра и развития новых выразительных средств балета. Их творчество отражает разнообразные жанры, фрормы, лексику и направления балетного театра в культуре Украины 1960-х гг.

Ключевые слова: украинский балетный театр, балетмейстеры-шестидесятники, балетный спектакль, выразительные средства.

\section{Lukyanenko Kateryna, Graduate student, Kiev National University of Culture and Arts}

\section{Creative searches of the Ukrainian ballet theater choreographers in the 1960s}

The purpose of the article is to identify the features of the creative activity of the sixties choreographers in the context of the evolution of the Ukrainian ballet theater of the "P. Shelest era" (1963-1972). Methodology. The method of historicism is applied (to study socio-political conditions and cultural trends of a particular period); cultural method, which helped to study the activities of the sixties choreographers in the context of the development of Ukrainian culture; methods of comparative analysis and stylistic approach aimed at determining the specifics of the choreographic structure of ballet performances, etc. Scientific novelty. The tendencies of development of Ukrainian ballet art in accordance with the specifics of socio-political and cultural life of 1963-1972 are determined; revealed the specifics of the creative search for sixties choreographers in the context of the evolution of the Ukrainian ballet theater of the "P. Shelest era"; The features of the interaction of folk and classical dance in the productions of the sixties choreographers are traced. Conclusions. The performances of the Ukrainian sixties choreographers are distinguished by the non-standard way of solving the images, originality, and individuality, they provide examples of innovative directorial decisions already performed by other choreographers of the productions and the first reading of choreographic works. Socio-political conditions and cultural and artistic trends of 1963-1972 reflected on the specifics of the evolution of the Ukrainian ballet theater, manifesting itself primarily in the intensification of attempts to expand the boundaries of the artistic language by using broad generalizing images, stylizing folk dance or its elements, moving to indirect quoting of folklore sources and enriching choreographic imagery in the context of the reflection of modern issues. Some representations of domestic sixties choreographers are positioned as reconnaissance of new ways in ballet art, which contributed to the formation of innovative trends in choreographic theater and the development of new expressive means of ballet. Their work reflects a variety of genres, forms, vocabulary, and directions of the ballet theater in the culture of Ukraine of the 1960s.

Key words: Ukrainian ballet theater, sixties choreographers, ballet performance, expressive means.

Вступ. Специфріка суспільно-політичного життя на Україні в 1963-1972 рр. - періоду правління першого секретаря ЦК КПУ П. Шелеста, а саме феномен його політики «українофільства», відобразилися на специфіці еволюціонування українського балетного театру. Розпочинається доба активізації новаторських перетворень, зумовлена творчими силами покоління молодих балетмейстерівпостановників, які прагнули поєднати індивідуальне авторське бачення сучасного балетного театру 3 кращими його традиціями - доба балетмейстерів-шістдесятників. Науковий інтерес до українського балетного мистецтва означеного періоду зумовлено наявністю ряду суперечливих факторів у сучасному балетному театрі, що знаходяться в безпосередньому змістовому зв'язку з попереднім періодом.

Мета статті - виявити особливості творчої діяльності балетмейстерів-шістдесятників у контексті еволюціонування українського балетного театру за «доби П. Шелеста (1963-1972рр.).

Аналіз досліджень засвідчив наявність багатьох наукових праць присвячених вивченню різноманітних аспектів українського балетного мистецтва XX ст., проте специфіка творчої діяльності балетмейстерів-шістдесятників лишається недостатньо висвітленою. Окремі питання означеної тематики знайшли відображення у наукових працях українських дослідників, присвячених аналізу регіональних особливостей балету, окремим балетним театрам, а також публікаціях, в яких предметом наукового дослідження стала творчість провідних балетмейстерів або артистів оперно-балетних театрів України. Наприклад, Є. Коваленко [4], А. Король [5], Л. Маркевич [6], Н. Семенової [8], О. Ущапівської [13] та ін.

Виклад основного матеріалу. Довготривала експлуатація позиціонування людини як «гармонійного, соціально повноцінного явища, як найвищої цінності демократичної культури та мистецтва» в тоталітарному суспільстві, на думку дослідників, призвела до принципового перегляду виключного положення людини в суспільстві. Натомість шістдесяті роки, порівняно з попереднім періодом, продемонстрували позитивне ставлення до проблем людини в сучасному для неї світі. Шістдесятництво мало 
яскраво виражений інтелектуальний характер і «природно впливало на світосприйняття сучасників, виховуючи їх в професіоналізмі та відчутті особистого, виключного призначення, що раптово знову стало актуальним» [1, 12].

Процеси, характерні для радянського соціомистецького простору 1960-х рр., дають підстави дослідникам вважати шістдесятництво розквітом гуманістичних ідей в контексті осмислення європейської культури та фрілософії XX ст., що стимулювало представників різних видів мистецтва орієнтуватися на духовні потреби суспільства, яке знаходилося на стадії побудови індустріальної держави [1, 3].

Поняття «балетмейстери-шестидесятники» розуміємо як культурний рух, народжений добою «відлиги» та виключно плідна балетмейстерська плеяда, творча діяльність якої великою мірою визначила стан сучасного українського балетного театру.

Серед балетмейстерів-шістдесятників, творчість яких найбільше вплинула на оновлення балетного театру в Україні, передусім у таких аспектах як поява та затвердження новаторських засобів хореографічної виразності, сучасної танцювальної образності, а також розширення жанрових, стильових та тематичних особливостей балетних вистав, були М. Арнаудова, В. Бойченко, Р. Візиренко-Клявін, Т. Дусметов, А. Пантикін, О. Сегаль, І. Чернишов, А. Шекера та ін. [11, 146]. Основою їх новаторської професійної творчості стали традиції хореографічного симфонізму та розвиток пластичного і танцювального різноманіття, підґрунтя якого було закладено ще Ф. Лопуховим.

Р. Володченко, розглядаючи режисерські прийоми для головний засобів драматичної виразності вистав хореографів 1960-х рр., аналізує вплив постановочних принципів вистав хореодрами та системи К. Станіславського на розвиток балету шістдесятників, осмислюючи роль режисерів драми в пошуку виражальних засобів балетної вистави тогочасними балетмейстерами. На думку дослідника, шістдесятники, зайнявши провідне положення в радянському балеті, як коли балетмейстери радянської хореодрами, не відмовилися від окремих важливих жанрових та формотворчих принципів попередників, а переосмисливши їх досягнення, запропонували власний шлях розвитку балетного театру. Зокрема, до найважливіших складових системи К. Станіславського, що здійснили значний вплив на діяльність балетмейстерів-шістдесятників та стали визначальними в їх балетних постановках, Р. Володченко називає «наскрізну дію», «надзавдання» та «зерно образу» [2, 27].

Аналізуючи специфіку даного аспекту діяльності балетмейстерів-шістдесятників, важливим $є$ звернення до особливостей хореодрами (першою хореодрамою українського балетного театру $є$ «Лілея» К. Данькевича у постановці Г. Березової, 1940 р.) [12, 186], з метою виявлення специфіки осмислення та застосування тотожних елементів у «драмбалеті» та хореографічному симфонізмі.

На думку мистецтвознавців, режисерське бачення балетмейстерів-шістдестників відсторонилося від реалістичного викладення сюжету твору, як це було за часів хореодрами в 1930-1950-х рр.: «не порушуючи зв'язок із традиціями класичного балету, взявши за основу сюжет літературного твору, шістдесятники не просто переносили його на балетну сцену, а переосмислювали, знаходили в ньому сучасне звучання» [2, 27-28].

Втім, деякі провідні українські балетмейстери-шістдесятники, зокрема А. Шекера, виховані на традиціях хореодрами, продовжували застосовувати її кращі досягнення, надаючи перевагу поетиці танцю [4, 37].

Оскільки балетна режисура, за Ю. Григоровичем, була здатна вирішувати завдання жанру, позбавленого прямолінійної логіки побудови, властивої драматичному театру, взаємодія між балетмейстерами та режисерами драми у 1960-х рр. була значно менш інтенсивною, в порівнянні з минулим періодом. Втім, загальний вплив режисури драми в 1960-х рр., як і протягом наступного десятиліття відчувається досить сильно, оскільки саме шляхом послідовного вибудовування епізодів дії (режисерський метод наскрізної дії) та логіки вчинків героїв вистав балетмейстери-шістдесятники досягали ефекту співпереживання, тобто персонального впливу танцю на глядача. Наприклад, наскрізний розвиток образу Марини - головної героїні балету «Поема про Марину» Б. Яровинського (балетмейстер В. Вронський, 1968 р.), на думку дослідників, доцільно позиціонувати як запоруку драматургічної цілісності вистави [5, 353].

Характерним для балетного театру України в 1960-х рр. є й тенденція оновлення жанрової палітри (поява ліричних поем, психологічних драм та балетів баладного характеру - «Сім красунь» К. Караєва, балетмейстер М. Трегубов; «Стежкою грому» К. Караєва, балетмейстер А. Шекера; «Легенда про любов» А. Мелікова, балетмейстер А. Шекера) [6, 77].

Л. Маркевич пропонує власну типологізацію постановок балетмейстерів-шістдесятників:

- балетні вистави присвячені сучасникам, що вирізняються наявністю певних ознак національної танцювальної культури - «Пісня про дружбу» Ю. Щуровського, «Орися» А. Кос-Анатольського, «Чорне золото» В. Гомоляки, «Торжество кохання» Ю. Знатокова, «Поема про Марину» Б. Яровинського;

- вистави, поставлені на нову балетну музику, відповідно якій було створено танцювальні образи-носії емоційно-психологічних барв, завдяки яким з'являлася можливість передавати різноманітні сюжетні колізії («Тіні забутих предків» В. Кирейка, постановка Т. Романової, 1960 р.; «Лілея» К. Данькевича, постановка А. Шекери, 1964 р.). 
Дослідниця стверджує, що як наслідок у балетному театрі України виникає багатозначна танцювальна стилістика, що синтезує «виразність класичного та народного українського танцю», оскільки саме завдяки зверненню до національної тематики, балетмейстери-постановники утверджували індивідуальний почерк застосування традиційних хореографічних засобів, в прагненні позбутися ілюстративності та поверховості естетики «драмбалету» [6, 76].

Оновлення репертуару балетних театрів означеного періоду відбувалося відповідно до пануючої ідеології - домінуючими стали вистави сучасної тематики, присвячені діяльності українських радянських людей, в яких нової якості набула не лише балетна музика Б. Буєвського, Ю. Рожавської, М. Сильванського, Б. Яровинського та ін., а й творчі експерименти балетмейстерів-шістдесятників, метою яких було збагачення виражальних засобів.

Зокрема йдеться і про балети-одноактівки і про кількаактові вистави: «Пісня про дружбу» Ю. Щуровського (постановник І. Ковтунов, Харківський театр опери і балету, 1961 р.), «Орися» А. КосАнатольського та «Останній бал» Ю. Бірюкова, Львівський оперний театр;, «Поема про Марину» Б. Яровинського, «Торжество кохання» Ю. Знатокова, «Чорне золото» В. Гомоляки (існують відомості, що постановка балету здійснена у співавторстві П. Вірського з балетмейстером-шістдесятником О. Сегалем та художником А. Петрицьким) та ін. [8, 112].

За словами Ю. Станішевського, «спираючись на власні творчі досягнення у створенні героїкоісторичних національних балетів, балетмейстери мусили йти далі, збагачуючи арсенал хореографічних прийомів, заснованих на синтезі класики й народного танцю, новими цікавими фрормотвореннями» [10]. Проте, у більшості випадків, при постановці балетів на сучасну тематику, ніби втрачалися творчі здобутки та розробки хореографічної балетної образності, винайдені та відшліфовані у виставах історичної тематики. Здебільшого, це пояснювалося недоліками лібретистів та композиторів, адже створення високохудожніх хореографічних сценічних постановок спирається у першу чергу на відповідний драматургічний зміст та музичну партитуру. Через відсутність матеріалу для творчої хореографічної роботи, такі вистави йшли не більше десятка разів і зникали з репертуару.

Перша та друга редакції балету «Чорне золото» В. Гомоляки, постановки яких здійснили М. Єфремов та О. Бредовський на сцені Донецького оперного театру і П. Вірський на київській сцені відповідно, засвідчили важливість надання героям виразних пластичних характеристик.

Т. Павлюк стверджує, що через позбавлення персонажів танцювального тексту, образи створені донецькими артистами Г. Кириліною (Марічка), О. Ковальовим (Івасик) та О. Фотіївим (Михайло) виявилися невиразними та безбарвними: «герої спілкувалися тут за допомогою побутової жестикуляції та пантоміми і лише в сценах випускного вечора та весілля витанцьовували банальні варіації та дуети» $[7,52]$.

Унікальну майстерність балетмейстера-постановника продемонстрував П. Вірський в процесі роботи над другою редакцією балету на сцені Київського державного театру опери та балету (до об'єднаного творчого складу входили і танцюристи Державного ансамблю танцю УРСР), який, за свідченням дослідників, не давав матеріалу для творчої роботи ані балетмейстеру, ані артистам [2, 176]. Критики, одностайно даючи найкращі рецензії на постановку в плані балетмейстерського рішення, хореографічних фрорм, у яких було синтезовано класичний та народно-сценічний танець, а також сценографрію А. Петрицького: «Поліфонічний та багатоплановий шахтарський масовий танець «У забої» 3 другої дії балету, коли по умовних штреках у єдиному пориві карбованим танцювальним кроком йшли стрункі лави забійників з сяючими гірницькими ліхтариками на формених кашкетах, вражав емоційною наснагою» [7, 52]; «Використана лише натяком імітація трудових процесів дала П.Вірському можливість накреслити незвичайний танцювальний малюнок. Чітка й винахідлива композиція танцю створила у глядача враження, що ряди шахтарів увесь час збільшуються, що їх трудовий ентузіазм зростає, і от, цілеспрямовані й натхненні, вони вже заповнюють усю сцену, а на кашкетах у них палають лампочки, розкидаючи снопи яскравих променів» [9, 44], акцентували лише на недоліках ілюстративноумоглядної музичної драматургії В. Гомоляки.

Створена спеціально для Третьої Декади української літератури та мистецтва, яка проходила у Москві 12-21 листопада 1960 р. балетна вистава, на яку було витрачено величезні фрінансові та творчі сили, була зіграна лише близька десяти разів, проте вдалий експеримент П. Вірського, що полягав у поєднанні лексики класичного танцю та виражальних засобів ансамблевих танцювальних фрорм, сфрормованих в межах народно-сценічного танцю, став основою для подальших творчих пошуків балетмейстерів-шістдесятників.

Одним із прикладів вдалого та високопрофесійного підходу стала спільна постановка М. Заславського та А. Шекери на сцені Львівського театру опери і балету ім. І. Франка балету «Орися» А. Кос-Анатольського, присвяченого боротьбі західноукраїнських робітників за власну свободу та щасливе життя.

Використання умовної танцювальної лексики посприяло органічній передачі пафосу революційної боротьби народу, образному та поетичному втіленню ідеї балетної вистави.

На думку тогочасних критиків, балетмейстерам вдалося зробити танець засобом зображення страждань трудового народу та відображення заповітних мрій героїв - видозмінені форми класичного танцювального тріо, замість традиційних пантоміми та позбавленої натуралістичності жестикуляції, 
завдяки майстерному виконанню Г. Ісупова (Лесь), Н. Слободян (Орися) та О. Поспєлова (Олекса), відтворювали зіткнення головних героїв [10]. Розв'язані танцювальними засобами драматичні картини у виставі (наприклад, сцена у концентраційному таборі) засвідчили втілення напруженої динаміки музики у симфонічній розробці пластичного малюнку, з метою посилення трагедійного звучання.

На основі автентичних фактів з історії партизанського руху в Україні було написано балет «Поема про Марину» Б. Яровинського, присвячений подвигу та героїчній загибелі богуславської комсомолки Марини Гризун (В. Калиновська), яку закатували німецько-фашистські загарбники під час окупації. Балет, постановку якого в 1968 р. здійснив В. Вронський, на думку А. Король, найбільш наближений до типу народної героїчної драми $[5,353]$, істотно вирізнявся 3-поміж інших балетних творів на сучасну тематику, засвідчив утвердження самобутнього українського балетного театру, завдяки реалізації оновлення традиційної балетної стилістики засобами синтезування різножанрових танцювальних елементів - класичного і народного танців із ритмізованою пантомімою $[6,76]$.

Фінал балету В. Вронський посилив героїчною патетикою, вирішивши найдраматичнішу сцену вистави - розстрілу комсомолки - аналогічно до епізоду з довженківського фрільму «Арсенал». Цілісний художній образ, узагальнюючий зміст якого було подано як символ, в деяких епізодах балетмейстеру вдалося створити завдяки органічному поєднанню хореографічної пластики та музики.

Одним із кращих зразків хореографічного симфонізму в творчості українських балетмейстерівшістдесятників є балетна вистава «Легенда про любов» А. Мелікова у постановці молодого балетмейстера, учня Р. Захарова Т. Дусметова (Донецький оперний театр, 1969 р.) [13, 126].

Оновлення хореографічної лексики стає однією з характерних рис балетних вистав, постановки яких на сцені Одеського театру опери та балету здійснили балетмейстери О. Тарасова, А. Лапаурі («Я ім'я твоє пишу...» на музику французького композитора Ф. Пуленка, 1968 р.) та О. Виноградов (триактовий балет «Попелюшка» С. Прокоф'ва, 1968 р.; комедійний балет «Марна обережність» Ж. Доберваля, 1972 р.).

Вистави вітчизняних балетмейстерів-шістдесятників позиціонуються як розвідка нових шляхів у балетному мистецтві, що сприяли формуванню новаторських тенденцій хореографічного театру та розвитку нових виражальних засобів балету. Їх творчість відображає різноманітні жанри, фрорми, лексику та напрямки балетного театру в культурі України 1960-х рр.

Наукова новизна. Визначено тенденції розвитку українського балетного мистецтва відповідно до специфіки суспільно-політичного та культурно-мистецького життя 1963-1972 рр.; виявлено специфріку творчих пошуків балетмейстерів-шістдесятників у контексті еволюціонування українського балетного театру за «доби П. Шелеста»; простежено особливості взаємодії народного та класичного танцю в постановках балетмейстерів-шістдесятників.

Висновки. Постановки українських балетмейстерів-шістдесятників за умов застосування загальних постановочних принципів, вирізняються нестандартністю вирішення образів, оригінальністю та яскравою індивідуальністю, а також репрезентують приклади новаторського режисерського рішення балетних вистав раніше здійснених іншими балетмейстерами та першопрочитання хореографічних творів. Величезну роль нова хореографічна лексика, що формувалася передусім завдяки органічному поєднанню класичного танцю на насиченого національним колоритом українського народносценічного (а радше стилізації елементів народного танцю), в постійному процесі провідних вітчизняних балетмейстерів збагатити танцювально-виражальні засоби хореографічного мистецтва, відіграла у балетних виставах про сучасників.

\section{תimepamypa}

1. Бондаренко Л. К. Тема деревни в творчестве советских живописцев 1960-1970-х годов : автореферат дис.. канд. искусствоведения : 17.00.04 / МГАХИ им. В. Н. Сурикова. Москва, 2005. 24 с.

2. Володченков Р. Г. Формирование художественных принципов в советском балете 1960-80-х годов (на примере творчества хореографа И. А. Чернышева): автореферат дис. канд. искусствоведения : 17.00 .01 / Российский университет театрального искусства - ГИТИС. Москва, 2015. 30 с.

3. Дорошенко В. Ф. Народно-сценічний танець як національне надбання хореографічної культури України. Культура України. 2013. Вип. 43. С. 150-158.

4. Коваленко Е. И. Анатолий Федорович Шекера - мастер балетного симфонизма и хореографической полифонии. Южно-российский музыкальный альманах. 2016. № 1(22). С. 37-42.

5. Король А. М. Жіночі образи в оригінальних балетах В. Вронського «Олеся» та «Поема про Марину». Вісник Національної академії керівних кадрів культури і мистецтв. 2018. № 4. С. 351-354.

6. Маркевич Л. А. До питання про модернізація художньої мови балетних вистав 60-80 років XX століття. Українська культура: минуле, сучасне, шляхи розвитку. 2018. Вип. 26. С. 75-84.

7. Павлюк Т.С. Українське балетмейстерське мистецтво (II половина XX ст.). Київ : Вид. центр КНУКіМ, 2017. $230 \mathrm{c}$.

8. Семенова Н. М. Феномен української національної балетної вистави: аналіз досліджень. Культура України. 2011. Вип. 35. С. 207-216.

9. Станішевський Ю. Павло Павлович Вірський. Народний артист СРСР. Київ : Мистецтво, 1962. 48 с.

10. Станишевский Ю. На пути к современной теме. Правда Украины. 1964. 2 дек.

11. Станішевський Ю. Балетний театр Радянської України, 1925-1985: шляхи і проблеми розвитку. Київ : Музична Україна, 1986. 235 с. 

1986. $237 \mathrm{c}$

12. Станішевський Ю.О. Український радянський балетний театр (1925-1975). Київ : Музична Україна,

13. Ущапівська О. М. Донецький театр опери та балету як територія не відчуженої комунікації. Мистецтвознавчі записки. 2014. Вип. 26. С. 123-130.

\section{References}

1. Bondarenko, L. K. (2005). The theme of the village in the works of Soviet painters of the 1960-1970s. Abstract of Ph.D. Moscow : Moscow State Art Institute named after V.N. Surikova. [in Russian].

2. Volodchenkov, R. G. (2015). Formation of artistic principles in the Soviet ballet of the 1960-80s (on the example of the work of the choreographer I. A. Chernyshev). Abstract of Ph.D. Moscow : Russian University of Theater Arts - GITIS. [in Russian].

3. Doroshenko, V. F. (2013). Folk-dance as a national heritage of choreographic culture of Ukraine. Culture of Ukraine, Issue 43, pp. 150-158. [in Ukrainian].

4. Kovalenko, E. I. (2016). Anatoly Fedorovich Sheker - master of ballet symphony and choreographic polyphony. South Russian musical almanac, no. 1 (22), pp. 37-42. [in Russian].

5. Korol A. M. (2018). Female images in the original ballets of V. Vronsky "Olesya" and "Poem about Marina". Bulletin of the National Academy of Art and Culture Leadership, no. 4, pp. 351-354. [in Ukrainian].

6. Markevich, L. A. (2018). To the question of the modernization of the artistic language of ballet performances 60-80 years of the twentieth century. Ukrainian culture: past, present, ways of development, Issue 26, pp. 75-84. [in Ukrainian]. Ukrainian].

7. Pavlyuk, T. S. (2017). Ukrainian Ballet Art (2nd half of the 20th century). Kiev: View. KNUCiM Center. [in

8. Semenova, N. M. (2011). The phenomenon of Ukrainian national ballet performance: analysis of research. Culture of Ukraine, Issue 35, pp. 207-216. [in Ukrainian].

9. Stanishevsky, Yu. (1962). Pavlo Virsky. People's Artist of the USSR. Kyiv: Art. [in Ukrainian].

10. Stanishevsky, Yu. (1964). On the way to the modern topic. True Ukraine. 2 Dec. [in Russian].

11. Stanishevsky, Yu. (1986). Ballet Theater of Soviet Ukraine, 1925-1985: ways and problems of development. Kyiv: Musical Ukraine. [in Ukrainian].

12. Stanishevsky, Yu. O. (1986). Ukrainian Soviet Ballet Theater (1925-1975). Kyiv: Musical Ukraine. [in Ukrainian].

13. Ushchapovskaya, O. M. (2014). Donetsk Opera and Ballet Theater as a territory of not alienated communication. Artistic notes, Vol. 26, pp. 123-130. [in Ukrainian].

Стаття надійшла до редакції 10.05.2019 p. 